\title{
Young athletes, beware
}

\author{
Cheng-Wen Cheng, Andy Li-Jen Liu
}

Department of Orthopedic Surgery, Cathay General Hospital, Taipei, Taiwan

\section{Correspondence to}

Dr Andy Li-Jen Liu, dmd00md05@gmail.com

\section{Accepted 16 April 2014}

\section{CrossMark}

To cite: Cheng C-W, Liu AL-J. BMJ Case Rep Published online: [please include Day Month Year] doi:10.1136/bcr-2014204738

\section{DESCRIPTION}

We present a case of a 15 year-old boy who experienced sudden left hip pain while sprinting. He had been training for the past 1 month and felt similar pain in his right hip 3 weeks earlier. Physical examination revealed severe tenderness near the left groin with limited flexion and abduction of the left hip. A radiograph showed a left anterior superior iliac spine (ASIS) avulsion fracture (figure 1) that was confirmed by CT, which also demonstrated a similar injury in the right hip (figures 2 and 3). Because the patient wanted to return to competition quickly, surgical fixation with screws was performed on the left hip while the minimally displaced injury in the right hip was treated conservatively. At 3-month follow-up, the patient had pain-free full range of hip movement and had returned to active sports without restriction.

ASIS avulsion fractures are rare injuries that occur predominantly in male adolescents involved in sports. ${ }^{1}$ They are caused by abrupt, powerful and vigorous contractions at the attachments of the sartorius and tensor fascia lata muscles to the ASIS, as well as by sudden directional changes. ${ }^{2}$ Diagnosis can be performed based on medical history and physical examination, and confirmed by radiological investigation. ${ }^{3}$ Conservative treatment through rest, analgesics and rehabilitation usually yields good functional results. Surgical intervention is rarely indicated and is reserved for when the fracture fragment has migrated more than $2-3 \mathrm{~cm}$, when meralgia paresthetica has occurred, when patients have failed conservative management or when they are eager for a quick recovery. ${ }^{1-3}$

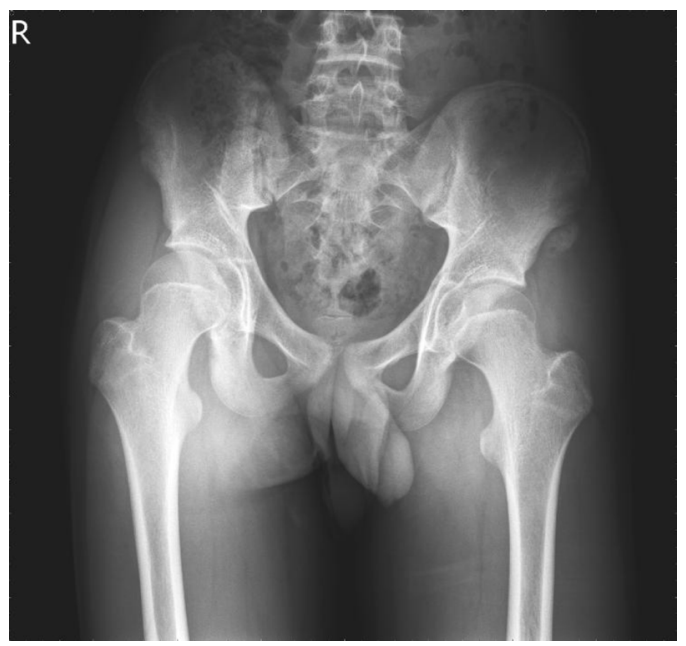

Figure 1 Anteroposterior radiograph of the pelvis demonstrating a left anterior superior iliac supine avulsion fracture.

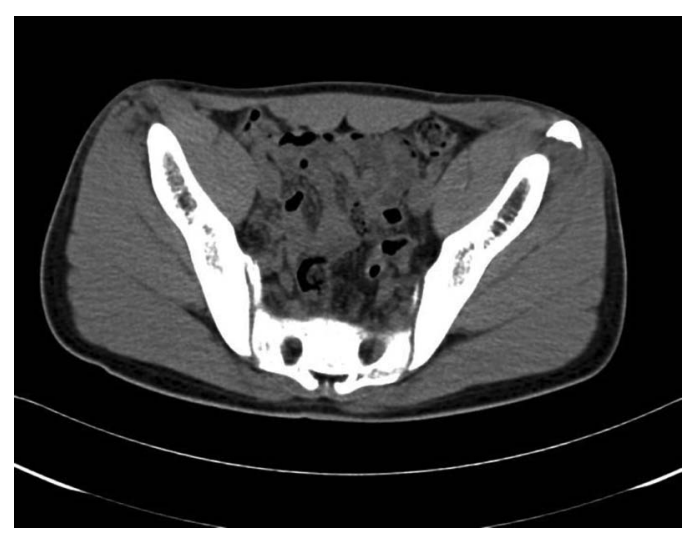

Figure 2 CT scan showing an avulsion fracture of the left anterior superior iliac spine with surrounding haematoma and soft tissue swelling.

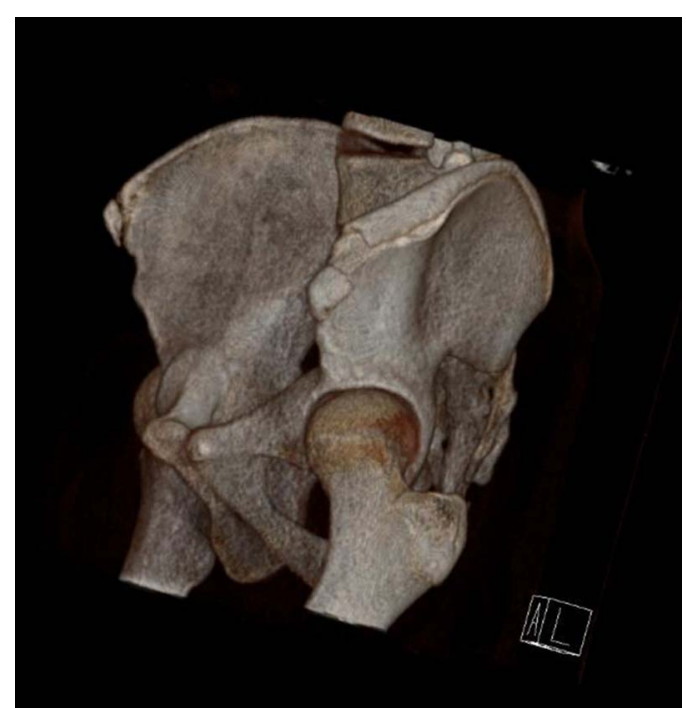

Figure 3 Reformatted CT scan showing an avulsion fracture of the left anterior superior iliac spine and a similar fracture on the right hip that is minimally displaced.

\section{Learning points}

- Anterior superior iliac spine (ASIS) avulsion fractures are rare injuries more common in boys involved in competitive sports such as sprinting, football and long-jumping.

- ASIS avulsion fractures are caused by a sudden and forceful muscular pull of the sartorius and tensor fascia lata on their ASIS attachments.

- The treatment of choice remains conservative; however, surgery can be performed depending on the degree of fracture displacement and the needs of individuals. 
Contributors C-WC was the primary surgeon who performed the surgery and was involved in the conception and design of this paper, along with revision and final approval of the paper before submission. AL was the first assistant during the surgery who was involved in the conception and design of this paper, and drafted the article for submission.

Competing interests None.

Patient consent Obtained.

Provenance and peer review Not commissioned; externally peer reviewed.

\section{REFERENCES}

1 Pointinger $H$, Munk P, Poescyhl GP. Avulsion fracture of the anterior superior iliac spine following apophysitis. Br J Sports Med 2003;37:361-2.

2 Rossi F, Dragoni S. Acute avulsion fractures of the pelvis in adolescent competitive athletes: prevalence, location and sports distribution of 203 cases collected. Skelet Radiol 2001;30:127-31.

3 Bendeddouche I, Jean Luc BB, Poiraudeau S, et al. Anterior superior iliac spine avulsion in a young soccer player. Ann Phys Rehabil Med 2010;53:584-90.

Copyright 2014 BMJ Publishing Group. All rights reserved. For permission to reuse any of this content visit http://group.bmj.com/group/rights-licensing/permissions.

BMJ Case Report Fellows may re-use this article for personal use and teaching without any further permission.

Become a Fellow of BMJ Case Reports today and you can:

- Submit as many cases as you like

- Enjoy fast sympathetic peer review and rapid publication of accepted articles

- Access all the published articles

- Re-use any of the published material for personal use and teaching without further permission

For information on Institutional Fellowships contact consortiasales@bmjgroup.com

Visit casereports.bmj.com for more articles like this and to become a Fellow 